\title{
小児用経鼻チューブの薬剤通過性
}

\author{
末丸克矢 $\dagger^{2 \mathrm{a})}$ ，川上賢哉 $\dagger^{2}$ ，市川裕規 $\dagger^{2}$ ，荒木博陽 $\dagger^{1}$, \\ 柴田和彦 $\dagger^{2}$ ，二神幸次郎 $\dagger^{2}$ ，五味田 裕 $\dagger^{2}$ \\ 愛媛大学医学部附属病院薬剂部 $\dagger^{1}$ \\ 岡山大学医学部附属病院薬剂部 $\dagger^{2}$
}

\section{The Passage of Medicines Through a Nasogastric Tube in a Pediatric Patient}

\author{
Katsuya Suemaru $\dagger^{2 a)}$, Kenya Kawakami $\dagger^{2}$, Hiroki Ichikawa $\dagger^{2}$, Hiroaki Araki $\uparrow^{1}$,

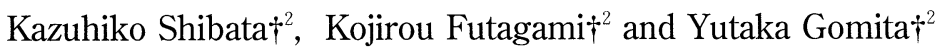 \\ Division of Pharmacy, Ehime University Hospital $\dagger^{1}$ \\ Department of Hospital Pharmacy, Okayama University Medical School $\dagger^{2}$
}

$\left[\begin{array}{lc}\text { Received October } 4,2002 \\ \text { Accepted February 1, } 2003\end{array}\right]$

\begin{abstract}
The administration of medicine using a nasogastric tube is occasionally used in epileptic patients with dysphagia. Such a tube occludes more frequently in pediatric patients than in adults, since the diameter of tube for a child is smaller than that for an adult. We therefore examined the passage of 28 medicines (13 antiepileptic drugs, 10 antibiotics, 2 medicine for intestinal disorders and 3 others) commonly used in pediatric epilepsy patients through a nasogastric tube for pediatric patients. The occlusion of the tube by medicines depended on the solubility and suspension of the medicine but not on the dosage form such as either fine powders or granules. The occlusion of the tube improved by the powderization of the medicine or increasing the diameter of the tube. Although some medicine did stick to the inner wall of the tube, such attachment was removed by washing out the tube with water. Providing this information to the doctor facilitated the rational prescription planning by confirming the diameter of tube and the medicine of the patients. In addition, the results of the current study are useful for pharmacists since they help in providing improved pharmaceutical care and counseling for pediatric epilepsy patients using a nasogastric tube.
\end{abstract}

Keywords - nasogastric tube, drug passage, antiepileptic drugs, pediatric epilepsy

\begin{abstract}
緒言
経鼻チューブを使用した経腸栄養剤や薬剂の投与は， 経口䝮取が不能な患者に沉用されている1,2)。一般的に， 経鼻チューブによる薬剤投与は経口投与と比べて飲み残 しや味などの問題がなく完全な量の投薬が行える。しか し，チューブに閉塞が生じた場合にはチューブの交換が 必要となり，介護者の負担となっている。特に，小児用
\end{abstract}

の経鼻チューブは成人用と比較して径が細いため, チューブの閉塞が起こりやすく処方設計や調剤にも注意 を要する。

小児の代表的な慢性疾患として小児てんかんがある。 てんかんの治療は抗てんかん薬による薬物治療が主であ り，規則正しい継続服用が発作のコントロールに必要と されている ${ }^{3,4)}$. 抗てんかん薬の飲み忘れや何らかの理 由により服薬が不能になった場合には血中濃度の低下に

$\dagger^{1}$ 愛媛県温泉郡重信町大字志津川454; 454, Shitsukawa, Shigenobu-cho, Onsen-gun, Ehime, 791-0295 Japan

$\dagger^{2}$ 岡山市鹿田町 2-5-1；2-5-1, Shikata-cho, Okayama-shi, 700-8558 Japan

a) 現：愛媛大学医学部附属病院薬剂部 
よりけいれん発作の再発やけいれん重積を誘発する危険 性があり ${ }^{3)}$, 嚥下障害を伴うてんかん患者に抢ける経鼻 チューブの閉塞はてんかんの薬物治療に支障をきたす。 しかしながら，経鼻チューブを使用している患者に合理 的な処方設計や調剤を行うための情報は少ない。そこ で，われわれは小児てんかん患者に繁用される薬剤につ いて経鼻チューブの通過性を調べ，その改善方法につい て検討した。

\section{方法}

小児てんかん患者への処方頻度が高い，抗てんかん 薬，抗生剂，抗コリン剂，整腸剂の溶解・懸濁性，閉塞 の有無㧍よびチューブ内への付着性について調べた。抗 生剂は $1.0 \mathrm{~g}$ を，その他の薬剤は $0.5 \mathrm{~g}$ を蒸留水 $5 \mathrm{~mL}$ に 溶かし，5秒間攪汼した後に試験管内における溶解・懸 濁性を「溶解，懸濁，ほとんど懸濁，懸濁しない」の 4 段階に分類し評価した。溶解・懸濁させた薬液は, $10 \mathrm{~mL}$ 用の注射シリンジに入れ，注射器より約 5 秒間かけて押 し出しチューブ閉塞の有無を調べた。閉塞した薬剤で水 剤のないものは，薬剤粉末化の効果を検討した。閉塞し なかった場合には，空気( $10 \mathrm{~mL}$ 分)を通してチューブ内 に残る溶液を押し出し，薬剤のチューブ内壁への付着を 調べた。次に，蒸留水 $5 \mathrm{~mL}$ をチューブ内に通した後の 薬剂の付着を調べた。なお，薬剤通過性の実験は，事前 に $5 \mathrm{~mL}$ の蒸留水を通過させた注射器と経鼻チューブを 用い, 注射器のプランジャー側を水平面より45度持ち上 げてチューブを垂直に保った状態で行った。薬剤の溶解 性, 閉塞, 付着の評価は 3 人の観察者で視覚的に行った. 経鼻チューブは 4 フレンチ(外径 $1.35 \mathrm{~mm}$, 長さ 40 $\mathrm{cm}), 6$ フレンチ (外径 $2.0 \mathrm{~mm}$, 長さ $40 \mathrm{~cm}), 8$ フレンチ (外径 $2.75 \mathrm{~mm}$, 長さ $80 \mathrm{~cm}$ ) の 3 種類 (アトム栄養カテー テル：アトム(侏) を使用し，薬剤の付着や閉塞が生じる まで再使用した。

以下に，今回チューブ通過性を調べた薬剂を示す. フェノバール10倍散(フェノバルビタール，藤永製薬 (㑣)，アレビアチン散10\%(フェニトイン，大日本製薬 (株)，デパケン細粒(バルプロ酸ナトリウム，協和発酵工 業(㭌)），テグレトール細粒(カルバマゼピン，ノバルティ スファーマ(秼)，リボトリール細粒(クロナゼパム，日 本ロシュ(株)，ベンザリン細粒(ニトラゼパム，塩野義製 薬(秼)，マイスタン細粒(クロバザム，(侏アズウェル）， エクセグラン散(ゾニサミド，大日本製薬(秼)，アア゙ロキ ザール散(リン酸ピリドキサール，鳥居薬品(姝)), 臭化カ リウム(山善製薬(侏)，ママイソリン細粒(プリミドン，大 日本製薬(侏)，エピレオプチマル(エトスクシミド，エー ザイ(株))，セルシン100倍細粒(ジアゼパム，武田薬品工
業(株)，セフゾン小児用細粒 (セフジニル，藤沢薬品工業 (株)，ハバナンドライシロップ(セフポドキシム・プロキセ チル，三共(侏)）、エリスロシンドライシロップ W(エリ スロマイシン，大日本製薬(侏)，サワシリン細粒(アモキ シシリン, 藤沢薬品工業(秼) , ミノマイシン顆粒 (ミノサ イクリン，日本ワイスレダリー(株)，ホスミシンドライ シロップ400(ホスホマイシンカルシウム，明治製菓 (株)，フロモックス小児用細粒(塩酸セフカペン・ピボキ シル，塩野義製薬(株)，メイアクト小児用細粒(セフジト レン・ピボキシル, 明治製菓(株)，，クラリスドライシロッ プ小児用(クラリスロマイシン，大正製薬(侏)，ユナシン 細粒小児用 (トシル酸塩スルタミシリン，ファイザー製 薬(株)，テルネリン顆粒(塩酸チザニジン，ノバルティス ファーマ(株)，アーテン100倍散(塩酸トリヘキシフェニ ジル，日本ワイスレダリー(侏)，ラックビー(乳酸菌製 率，日研化学(侏)，エンテロノン-R(乳酸菌製剂，アベン ティスファーマ(㧣)，EFC乳糖(乳糖，メルク・ホエ イ(侏).

\section{結果}

Table 1 に，抗てんかん薬のチューブ通過性を示す. 水に溶解した薬剤(臭化カリウム) と懸濁性が良好な薬剂 は，今回検討を行ったチューブの中で最小の径である 4 フレンチのチューブを通過し閉塞することはなかった。 デパケン細粒，エクセグラン散，マイソリン細粒拉よび セルシン散は水に懸濁せず直に沈殿した。その沈殿薬剤 が注射シリンジやチューブの先端で閉塞した。中でも， デパケン細粒，マイソリン細粒，セルシン散は，8フレ ンチのチューブでも閉塞した。エクセグラン細粒は 6 フ レンチで閉塞したが，8フレンチでは通過した。閉塞し た薬片うち水剤のない薬剤について粉末化の影響を検討 した，その結果，エクセグラン散は 4 フレンチで，マイ ソリン細粒は 8 フレンチで通過するようになり通過性の 改善がみられた。なお，空気 $10 \mathrm{~mL}$ を通して溶液を押し 出した後に薬剤の付着を確認すると，テグレトール細 粒，リボトリール細粒，粉末化エクセグラン細粒ならび に粉末化マイソリン細粒で付着が認められた。しかし， これらの付着は水 $5 \mathrm{~mL}$ のフラッシュにより洗い流すこ とができた。

Table 2 には，抗てんかん薬以外のチューブ通過性を 示す．抗てんかん薬の場合と同様に，㲘濁性が良好な薬 剂はすべて 4 フレンチのチューブを通過した。懸濁性が 悪かったフロモックス細粒とユナシン細粒は 4 フレンチ のチューブで閉塞した。しかし，両薬剤とも6フレンチ に径を大きくすると通過した。な扔，アーテン散，エリ スロシンドライシロップ，ホスミシンドライシロップで 
Table 1. 抗てんかん薬のチューブ通過性

\begin{tabular}{|c|c|c|c|c|c|}
\hline \multirow{2}{*}{ 薬剤名 } & \multirow{2}{*}{$\begin{array}{l}\text { 溶解性 - } \\
\text { 懸濁性 }\end{array}$} & \multirow{2}{*}{$\begin{array}{r}\text { チューフフ } \\
(\mathrm{Fr} .)\end{array}$} & \multirow{2}{*}{ 閉塞 } & \multicolumn{2}{|c|}{ 付着性 } \\
\hline & & & & 空気通し後 & 水通儿後 \\
\hline 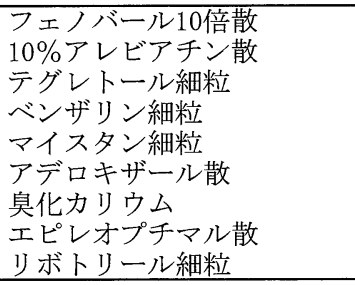 & $\begin{array}{l}\bigcirc \\
\bigcirc \\
\bigcirc \\
\bigcirc \\
\bigcirc \\
\bigcirc \\
\text { 溶解 } \\
\bigcirc \\
\bigcirc \\
\end{array}$ & \begin{tabular}{l|}
4 \\
4 \\
4 \\
4 \\
4 \\
4 \\
4 \\
4 \\
4 \\
\end{tabular} & $\begin{array}{l}0 \\
\bigcirc \\
\bigcirc \\
\bigcirc \\
\bigcirc \\
\bigcirc \\
\bigcirc \\
\bigcirc \\
0\end{array}$ & $\begin{array}{l}0 \\
0 \\
\triangle \\
0 \\
0 \\
0 \\
0 \\
0 \\
\triangle\end{array}$ & $\begin{array}{l}0 \\
\bigcirc \\
0 \\
0 \\
0 \\
0 \\
0 \\
0 \\
0\end{array}$ \\
\hline エクセグラン散 & $x$ & $\begin{array}{l}4 \\
6 \\
8\end{array}$ & $\begin{array}{l}\times \\
\times \\
\bigcirc\end{array}$ & $\triangle$ & 0 \\
\hline 粉末化・エクセグラン細粒 & $\triangle$ & 4 & 0 & $\triangle$ & 0 \\
\hline マイソリン細粒 & $x$ & $\begin{array}{l}6 \\
8 \\
\end{array}$ & $\begin{array}{l}x \\
x\end{array}$ & & \\
\hline 粉末化・マイソリン細粒 & $\triangle$ & $\begin{array}{l}4 \\
6 \\
8 \\
\end{array}$ & $\begin{array}{l}\times \\
\times \\
\bigcirc\end{array}$ & $\triangle$ & 0 \\
\hline デパケン細粒 & $x$ & $\begin{array}{l}6 \\
8 \\
\end{array}$ & $\begin{array}{l}x \\
x \\
\end{array}$ & & \\
\hline セルシン散 & $x$ & $\begin{array}{l}6 \\
8\end{array}$ & $\begin{array}{l}x \\
x \\
\end{array}$ & & \\
\hline
\end{tabular}

溶解性・懸濁性 : 溶解、懸濁 $(O)$ 、ほとんど懸濁 $(\triangle)$ 、懸濁しない $(x)$ 閉塞 : 閉塞なし $(O)$ 、閉塞あり $(\times)$

付着 : 付着なし $(\bigcirc)$ 、付着あり $(\triangle)$

Table 2. 抗てんかん薬以外のチューブ通過性

\begin{tabular}{|c|c|c|c|c|c|}
\hline \multirow{2}{*}{ 薬剤名 } & \multirow{2}{*}{$\begin{array}{c}\text { 溶解性・ } \\
\text { 彩濁性 }\end{array}$} & \multirow{2}{*}{$\begin{array}{r}\text { チューブ } \\
\text { (Fr.) }\end{array}$} & \multirow{2}{*}{ 閉塞 } & \multicolumn{2}{|c|}{ 付着性 } \\
\hline & & & & 空気通し後 & 永通し後 \\
\hline テルネリン顆粒 & 0 & 4 & O & 0 & 0 \\
\hline アーテン散 & 0 & 4 & 0 & $\triangle$ & 0 \\
\hline ラックビー & 0 & 4 & 0 & 0 & 0 \\
\hline エンテロノン-R & 0 & 4 & 0 & 0 & 0 \\
\hline $\mathrm{EFC}$ 乳糖 & 0 & 4 & O & 0 & 0 \\
\hline セフゾン細粒小児用 & 0 & 4 & 0 & 0 & 0 \\
\hline バナンドライシロップ & 0 & 4 & 0 & 0 & 0 \\
\hline エリスロシンドライシロップ & O & 4 & O & $\triangle$ & 0 \\
\hline クラリスドライシロップホ児用 & 0 & 4 & 0 & 0 & 0 \\
\hline サワシリン細粒 & 0 & 4 & 0 & 0 & 0 \\
\hline ミノマイシン顆粒 & 0 & 4 & 0 & 0 & 0 \\
\hline メイアクト小児用細粒 & 0 & 4 & 0 & 0 & $\bigcirc$ \\
\hline ホスミシンドライシロップ & 0 & 4 & 0 & $\triangle$ & 0 \\
\hline フロモックス小児用細粒 & $\triangle$ & 4 & $x$ & & \\
\hline & & 4 & $\bar{x}$ & & \\
\hline ユナシン細粒小児用 & $\triangle$ & 6 & $\hat{0}$ & 0 & 0 \\
\hline
\end{tabular}

溶解性・懸濁性 : 溶解、懸濁 $(O)$ 、ほとんど懸濁 $(\triangle)$ 、懸濁しない $(\times)$

閉塞：閉塞なし $(O)$ 、閉塞あり $(X)$

付着：付着なし $(\bigcirc)$ 、付着あり $(\triangle)$

チューブ内壁への付着がみられたが，水のフラッシング により除くことができた。

\section{考察}

曼下障害や哺乳障害のため経鼻チューブを使用して抗 てんかん薬を服用している患者では，重度の脳機能障害 や発達障害を伴っている場合がある，その場合，併用薬 剂数も多く，チューブの使用が長期にわたるため，閉塞 によるチューブの交換は介護者(主に母親)の大きな負担 となっている．新生児では 4 フレンチのチューブが使用 され，その後は成長に伴って 6 や 8 フレンチのチューブ
が使用されている。一般的に，小児においてはチューブ の径が小さいため, 薬剤によるチューブの閉塞が起こり やすく注意を要する。しかし，処方設計を行う医師は薬 剂の溶解性やチューブ通過性の情報が少ないため, チューブ閉塞の訴えがあった場合に取りあえず細粒や顆 粒に粉末化の指示をしているのが現状である．当院にお いて，小児てんかん患者に服薬指導を行っている薬剤師 もチューブに閉塞の問題が生じた場合にはその都度 チューブ通過性を調べ対応していた。今回われわれは， 事前にチューブの閉塞を防ぐことならびに合理的な処方 設計や調剤を行うことを目的に，小児てんかん患者に繁 
医療薬学 Vol. 29,No. 3 (2003)

340

用されている薬剂の経鼻チューブ通過性を検討した。

今回の検討により，水に溶解した薬剤または懸濁性の 高い薬剤はチューブ通過性が良好であることが確認され た。しかし，水にほとんど溶解せず沈殿する薬剤や懸濁 しても大きい粒子が残る薬剤は注射シリンジやチューブ の先端で閉塞が生じた。すなわち, 薬剤の水への溶解 . 懸濁状態を確認すればある程度チューブ閉塞の可能性を 予測できるものと思われる，薬剤のチューブ閉塞の改善 方法として, 松田ら ${ }^{5}$ らはガストローム顆粒について検 討し，粉末化が有効であったことを報告している．著者 らの結果においても，粉末化やチューブの径を大きくす ることにより多くの薬剤で通過性が改善された。しか し，粉末化することによる製剂の安定性や体内動態の変 化に留意しなければならない。例えば，デパケン細粒は 主薬のバルプロ酸ナトリウムに潮解性があることや ${ }^{6)}$, フェニトインは粒子径によって吸収が異なること7が知 られている。したがって，デパケン細粒やセルシン散の ようにシロップ剤のある薬剤については水剤へ変更し, 他の剤形がないものに限り粉末化の検討を行うことが望 ましいと考えられる。

経腸栄養剤の注入後には, 必ず微温湯をチューブ内に 注ぎ洗浄を行うことが必要とされている1).一方, 薬剤 の付着性に関しても, 粉末化したガストローム顆粒は チューブ内に付着することから，水などによるフラッシ ングの必要性が報告されている5 ．著者らの検討におい ても，薬剤注入後にチューブ内に付着する薬剤があっ た.しかし，これらの付着した薬剤のすべては $5 \mathrm{~mL} の$ 水で洗い流すことができた。したがって，薬剤注入後に も水などで洗浄を行うことを介護者に指導する必要性が あると考えられる。

今回の検討においては, 各薬剂単剂で一定量のチュー ブ通過性を視覚的に評価した。ささらに詳細な付着性を明 らかにするためには，薬剤の回収率で評価することが必 要と考えられる，また，経鼻チューブを使用して薬郕を 注入している患者では複数の薬剂を併用している場合が 多く, 介護している家族は数種の薬剤をまとめて水に溶 かし注入することがある。したがって，実際の処方では 注入量も異なってくることから，処方が変更になった時 などは薬剤のチューブ通過性に留意する必要がある.

今回の検討によって得られたチューブの通過性の結果 を一覧表 $($ Table 3 ) にまとめ, 関連医師や医局に情報提 供した。医師は患者が使用しているチューブの径と薬剤 を確認することにより合理的な処方設計を行うことがで きるようになり，薬剤師も調剤にかかる時間を短縮させ ることができた。 さらに, 服薬指導を行っている薬鼡師 は服薬指導時にチューブ閉塞の確認を行うと同時に
Table 3. 抗てんかん薬を中心とした薬剤の経鼻チューブ 通過性

\begin{tabular}{|c|c|c|c|c|}
\hline 薬 剂 名 & $\begin{array}{l}\text { 溶解性 } \\
\text { 懸濁性 }\end{array}$ & $\begin{array}{c}\text { チューブ } \\
\text { (Fr) }\end{array}$ & $\begin{array}{l}\text { チューブ } \\
\text { 通過性 }\end{array}$ & 備 \\
\hline \multicolumn{5}{|l|}{ 抗てんかん薬 } \\
\hline フェノバール10偣散 & 0 & $\mathrm{Fr} 4$ & 0 & \\
\hline 10\%アレビアチン散 & 0 & Fr 4 & 0 & \\
\hline テグレトール細粒 & 0 & Fr 4 & 0 & \\
\hline ベンザリン細粒 & 0 & Fr 4 & 0 & \\
\hline マイスタン細粒 & 0 & Fr 4 & 0 & \\
\hline エピレオプチマル散 & 0 & Fr 4 & 0 & \\
\hline アデロキザール散 & 0 & Fr 4 & 0 & \\
\hline 臭化カリウム & 溶解 & Fr 4 & 0 & 粉末化不要 \\
\hline リホトトリール細粒 & 0 & $\operatorname{Fr} 4$ & 0 & 粉末化不要 \\
\hline エクセグラン散 & $x$ & $\begin{array}{l}\text { Fr } 6 \\
\text { Fr } 8\end{array}$ & $\stackrel{x}{\circ}$ & \\
\hline エクセグラン細粘(粉末化) & $\triangle$ & $\begin{array}{ll}11 & 0 \\
\operatorname{Fr} & 4 \\
\end{array}$ & 0 & 粉末化有効 \\
\hline マイソリン細粒 & $x$ & Fr 8 & $x$ & \\
\hline マイソリン細粒(粉末化) & $\triangle$ & $\begin{array}{ll}\text { Fr } & 6 \\
\text { Fr } & 8 \\
\end{array}$ & $\begin{array}{l}x \\
0\end{array}$ & 粉末化有効 \\
\hline デパケン細粒 & $x$ & Fr 8 & $x$ & シロップ剂へ \\
\hline セルシン散 & $x$ & Fr 8 & $x$ & シロップ剂へ \\
\hline \multicolumn{5}{|l|}{ 抗生剂 } \\
\hline $\begin{array}{l}\text { 七フンンン細粒 } \\
\end{array}$ & 0 & Fr 4 & 0 & \\
\hline バナンD S & 0 & Fr 4 & 0 & \\
\hline エリスロシンDS & 0 & Fr 4 & 0 & \\
\hline クラリスDS & 0 & Fr 4 & 0 & \\
\hline サワンリン細粒 & 0 & Fr 4 & 0 & \\
\hline ミノマイシン顆粒 & 0 & Fr 4 & 0 & \\
\hline メイアクト絽粒 & 0 & Fr 4 & 0 & \\
\hline ホスミシンDS & 0 & Fr 4 & 0 & \\
\hline フロモックス細粒 & $\triangle$ & $\begin{array}{ll}\text { Fr } & 4 \\
\text { Fr } & 6\end{array}$ & $\begin{array}{l}x \\
0\end{array}$ & \\
\hline ユナシン細粒 & $\triangle$ & $\begin{array}{ll}\text { Fr } & 4 \\
\text { Fr } & 6\end{array}$ & $\begin{array}{l}x \\
0\end{array}$ & \\
\hline \multicolumn{5}{|l|}{ その他 } \\
\hline テルネリン顆䊀 & 0 & Fr 4 & 0 & 粉末化不要 \\
\hline アーテン散 & 0 & Fr 4 & 0 & \\
\hline ランックビー & 0 & Fr 4 & 0 & \\
\hline エンテロノン-R & 0 & Fr 4 & 0 & \\
\hline EFC 乳糖 & 0 & $\operatorname{Fr} 4$ & 0 & \\
\hline
\end{tabular}

チューブ閉塞に関する適切な情報を患者・家族に提供で きるようになった。

\section{引用文献}

1）島田慈彦, 佐川賢一, 松原肇, “経腸・経静脈栄養 療法の基礎と実際”,薬事日報社，東京，1998， pp. 15-61.

2）赤松洋, 哺乳障害, 小児看護, 18, 1217-1221(1995).

3）大田原俊輔, “小児神経科からみたてんかん「臨床 小児脳神経外科学」”, 松本悟, 大井静雄編, 医学 書院，東京，1992, pp.667-681.

4）荒木博陽，五味田裕，てんかん治療薬と患者への 説明，薬局 50，30-40(1999).

5）松田三郎, 石川茂行, 岸谷敏男, 小森俊伸, 経管 栄養チューブを用いたカストローム顆粒の通過性 の検討，新薬と臨床，48，627-631(1999).

6) デパケン医薬品インタビューフォーム, 協和発酵 工業株式会社, 1996年改訂.

7）兼子直, 和田一丸, 抗てんかん薬の薬物動態, 医 学のあゆみ，183，114-119(1997). 